\title{
NAGYVÁLLALATOK LOGISZTIKAI DOKUMENTÁCIÓS FOLYAMATAINAK FELTÉRKÉPEZÉSE
}

\author{
Nagy Lili \\ BSc hallgató, Miskolci Egyetem, Logisztikai Intézet \\ 3515 Miskolc, Miskolc-Egyetemváros, e-mail: nagylili98@gmail.com \\ Bányai Tamás \\ egyetemi docens, Miskolci Egyetem, Logisztikai Intézet \\ 3515 Miskolc, Miskolc-Egyetemváros, e-mail: alttamas@uni-miskolc.hu
}

\begin{abstract}
Absztrakt
A 21. században az egyik, ha nem a legfontosabb „fegyver” az információ. Felgyorsult világunkban mindenki azonnal tudni szeretne mindent, illetve a cégeknek is csak úgy van esélye talpon maradni, ha azonnali, naprakész információt biztositanak. Ezen igények következtében zajlik napjainkban egy digitalizációs forradalom, ismertebb nevén az Ipar 4.0, amelynek megoldásai alapjaiban fogják megváltoztatni a versenyszférát és a munkaeröpiacot. A digitalizáció megkönnyíti a kommunikációt, az információ gyorsabb, pontosabb áramlását teszi lehetövé és számos új technológiát eredményez. Ezek bevezetéséröl viszont a vállalatok vezetése és a munkavállalók között nem feltétlen van egyetértés. Azon vállalatok, amelyek nem lesznek képesek lépést tartani, most könnyebben elveszithetik akár piacvezetö szerepüket, mint valaha. Jelen cikk keretében a szerzök bemutatják a digitalizáció jelentöségét és kihivásait a nagyvállalatok életében, valamint a vállalati logisztikában.
\end{abstract}

Kulcsszavak: digitalizáció, dokumentációs folyamatok, logisztika, Ipar 4.0

\begin{abstract}
In the 21 st century, one of the most important, if not the most important "weapon" is information. In our accelerated world, everyone wants to know everything right away, and companies only have a chance to stay afloat if they provide instant, up-to-date information. As a result of these demands, a digital revolution is taking place today, better known as Industry 4.0, whose solutions will fundamentally change the competitive sphere and the labour market. Digitization facilitates communication, allows information to flow faster and more accurately, and results in a number of new technologies. However, there is not always an agreement between the management of the companies and the employees about their introduction. Companies that will not be able to keep up are now more likely to lose even their market leadership than ever before. In this paper, the authors present the importance and challenges of digitization in the lives of large companies as well as in corporate logistics.
\end{abstract}

Keywords: digitisation, documentation processes, logistics, Industry 4.0 


\section{Bevezetés}

A vállalatok iparterületén szerteágazó és komplex logisztikai feladatok vannak. Ezen logisztikai területek folyamatos optimalizálása, valamint a munkaerő folyamatos képzése és a logisztikai rendszerek átszervezése is jelentős beruházásokat igényel.

A digitalizációnak köszönhetően számtalan optimalizálási lehetőség van, azonban egyelöre ez csak a nagyvállalatok költségvetésébe fér bele. Az optimalizálás egyik kulcstényezöje a dokumentáció. Nagy- és multinacionális vállalatok különböző részlegei között gyakran előfordul, hogy nincsenek vagy nem használnak egységes eljárásokat dokumentációk elkészítésére és feldolgozására. Ezen problémák kezelése jelentős költségekkel bír, amely nagyrészt az információ kezeléséhez szükséges eszköz- és humánerőforrás költségeiből tevődik össze. Nagyvállalati környezetben lehetőség van a különböző területek harmonizációjára és digitalizációjára, sőt messzemenő célként megfogalmazódhat a humánerőforrás részleges vagy akár teljes kiváltása egyes szintekről. Ebből adódóan felmerül az a lényeges kérdés, hogy egy ilyen lépés után, mely területekre képezhető vagy csoportosítható át a digitalizáció által kiváltott munkaerő. Emellett érdemes megvizsgálni a gazdaságra és a vállalatok cégstruktúrájára történő hatásokat. Ezt is mutatja az, hogy különböző részlegeken a technológiai újítások bevezetése más-más megtérülési rátával rendelkezik, illetve a nagymértékü fejlesztés szükségessége megkérdőjelezhető.

A nagyvállalati problémák sorát erősíti az, ha egy új üzem vagy részegység épül a vállalat területén megterhelve a telephely infrastruktúráját. A cikkben kifejtésre fog kerülni, hogy ezen problémák mindegyikére hogyan és miként tud megoldást jelenteni egyetlen ERP rendszer.

A múltban és a jelenben is visszaköszönnek ugyanazok a problémák, felvetések. Lassan 15 éve a vállalatok még ágazataik kiszervezésben hittek, ma mégis teljesen máshogy reagálnak a fennálló krízisekre. Ennek oka a fejlődés, hogy tanulunk hibáinkból és alkalmazkodunk a változó világhoz.

Az új beruházások elkerülhetetlenné váltak, valamint a humán erőforrás továbbképzése is nélkülözhetetlen. Ez az új irány egyszerre rugalmasabbá és versenyképesebbé teszi a cégeket és ezek által új kihívások elé is állítja őket.

Napjainkban a piaci igények a valós idejü adatfeldolgozás és információközlés felé irányulnak. Ez megnyilvánulhat többek kötött abban, hogy a még gyártósoron levő termékek már a világ bármely pontján láthatóak legyenek, mint azonnal eladható listás cikkek, amikről minden információ és megfelelő dokumentáció rendelkezésre áll. Ezeket véleményünk szerint úgy lehet a legkönnyebben elérni, ha rendelkezésre állnak a megfelelő dokumentumok, a megfelelő módon, a megfelelő időben, és a megfelelö eszközökön.

Ezek természetesen fontosak és alapfeltevések a vásárló feleknek, mert egy cég ezen dokumentumok meglétével tudja igazolni az eredetiségét, az áru nyomon követhetőségét, szállíthatóságát és a tanúsítványok meglétét. Azonban kevés szó esik arról, hogyan készülnek ezek és milyen terheket rónak ezen dokumentumok előállításai az érintett gyártókra úgy, hogy a felmerülő „,dokumentációs” többlet költségeket gyakran, avagy a legtöbb esetben nem tudják érvényesíteni áraikban. A piacon számos dokumentáció-menedzsment szoftver található [1-9], melyek megoldást jelenthetnek a cikkben felvetett részfeladatok megoldására, azonban a teljeskörü megoldás érdekében elengedhetetlen az ERP-vel való integráció mellett a rendelkezésre álló korszerü, Ipar 4.0 technológiákként aposztrofált megoldások alkalmazása.

A logisztikai folyamatokra, különösen nagyvállalati környezetben, egyre nagyobb hatást gyakorol a lean filozófia. Olyan területeken jelenik meg a lean filozófia különböző mélységú alkalmazása, mint a hagyományos és additív gyártás [10], érinti nem csupán a gyártási folyamatot, hanem az ahhoz kapcsolódó teljes ellátási láncot $[11,12]$ és egyre kiterjedtebb mértékben alkalmazza az Ipar 4.0 
technológiákat, különösen a szenzorhálózatokat [13]. Nagyvállalati környezetben az ismert lean eszközök használata mellett [14] a folyamatfejlesztés fontos eszközévé vált a szimuláció $[15,16]$. A lean filozófia olyan speciális területeken is jelentős fejlesztések megvalósítására adott lehetőséget, mint a fafeldolgozás [17] vagy az építőipar [18], ugyanakkor megjelent a gyártás biztonságát jelentős mértékben befolyásoló karbantartás területén is [19].

Jelen cikk keretében a szerzők bemutatják a dokumentumok előállításának és menedzselésének azon Ipar 4.0 aspektusait, melyek révén nagymértékben növelhető a vásárlók bizalma és hosszútávon csökkenthetőek a költségek.

\section{Nagyvállalati logisztikai környezet}

A kutatómunka keretében vizsgált nagyvállalat esetében a csökkentése érdekében a vállalatnak optimalizálnia kellett az ellátási láncot, azonban a 2000-es évek elején erre csak az alábbi lehetőségek voltak adottak: tevékenységek bővítése, váltás, megszüntetés; termelésoptimalizálás, kapacitáskihasználás növelése; folyamatoptimalizálás; készletoptimalizálás; szállításoptimalizálás; kiszervezés. Ezért 2006-ban a vállalat akkori vezetése logisztikai szegmens kiszervezése mellett döntött.

Számos vállalat kiszervezi azon szektorait, melyek nem tartoznak a fö fókuszterületei közé, így optimalizálva azt. Ennek oka, hogy gazdaságilag müködtetni egy ágazatot megfelelő háttér és infrastruktúra nélkül jelentősen költségesebb, mint azon cégeknek, akik a területre specializálódtak. Jellemzően a költségvetés csökkentése mellett, a folyamatosan változó igények és a megnövekedett komplex logisztikai feladatok miatt dönt egy cég a kiszervezés mellett, így fenntarthatóvá téve az ágazat minőségét és hatékonyságát. A logisztika kiszervezésével a vizsgált nagyvállalat az alábbi célokat tüzte ki a szegmensre vonatkozóan: rugalmasság növelése, piacvezető szerep elérése, minőség növekedése, belépés új piacokra, szolgáltatások bővítése, munkaerő képzettségének növelése, innovatív technológiák bevezetése, alapvető üzleti folyamatokra való összpontosítás, müködési költségek csökkentése, tőkeberuházások csökkentése, $\mathrm{K}+\mathrm{F}$ költségek csökkentése, egészségügyi költségek minimalizálása, fix költségek változóvá alakítása.

A vizsgált iparterületen szerteágazó és komplex logisztikai feladatok vannak. A logisztika tevékenységi körébe tartozik a dokumentáció, információ feldolgozás, késztermékek átszállítása a silóparkba, kiszerelési feladatok, készletek nyomon követése, kiszállítások menedzselése és egyéb szolgáltatási feladatok. Ezen logisztikai területek folyamatos optimalizálása, valamint a munkaerö folyamatos képzése és a logisztikai rendszerek átszervezése is jelentős beruházásokat igényelt volna abban az időben. A döntéseket az alábbi módszerekkel hozták meg: döntési helyzet feltárása, egyszerüsítő felvetések, döntési változók azonosítása, választási lehetőségek, korlátozó feltételek számbavétele, kritériumok, célfüggvény, optimum- minimum és maximum (meghatározott vevökiszolgálás szint elérése a legkisebb költséggel és a rendelkezésre álló eszközökkel).

Ezekre a döntési módszerekre azért volt szükség, mert a kiszervezések nem mondhatók kockázatmentesnek. Ha a megrendelő nem határozza meg elég pontosan az elvárásait és a feladatokat a kiszervezéstől várt eredmények nem lesznek pozitívak. A sikertelen kiszervezésnek még a szervezeten belüli ellenállás, a szigorú szerződés hiánya is tényezője lehet.

Ezért nagyon fontos, hogy a megrendelő kidolgozza a módszereket és a lépéseket, illetve le is szabályozza azokat a kiszervezés előtt, valamint alkalmazzon kiválasztási és értékelési rendszert, folyamatos kockázatmenedzselést, hatásvizsgálatokat és határidőrendszert. További siker tényezők: win- win alapú szerződés, átlátható működés és éves elszámolás, teljesítmény elszámolás vagy tarifális rendszer, hibák azonnali visszajelzése, kötbérrendszer, szolgáltatói rugalmasság. 
Nagyvállalati környezetben a vállalatirányítási rendszerek egy jó alapot teremtenek a dokumentációs folyamatok korszerü, megbízható és hatékony megoldására, azonban a napjainkban rendelkezésre álló egyéb korszerủ technológiai megoldások révén (digitális iker, felhő- és ködalapú számítások, big data megoldások, rádiófrekvenciás termékazonosítás, mobil robotok, autonóm gyártás) ezen dokumentációs folyamatok vállalatirányítási rendszerekkel történő integrációja még hatékonyabban valósítható meg, illetve az integráció révén az üzleti partnerekkel való együttmüködés is javítható, nem beszélve a vásárlói kapcsolatok és a vásárlói bizalom fokozására gyakorolt hatásokról, melyek nem csupán naturális, hanem költségmutatókkal is számszerüsíthető eredményjavulást hozhatnak.
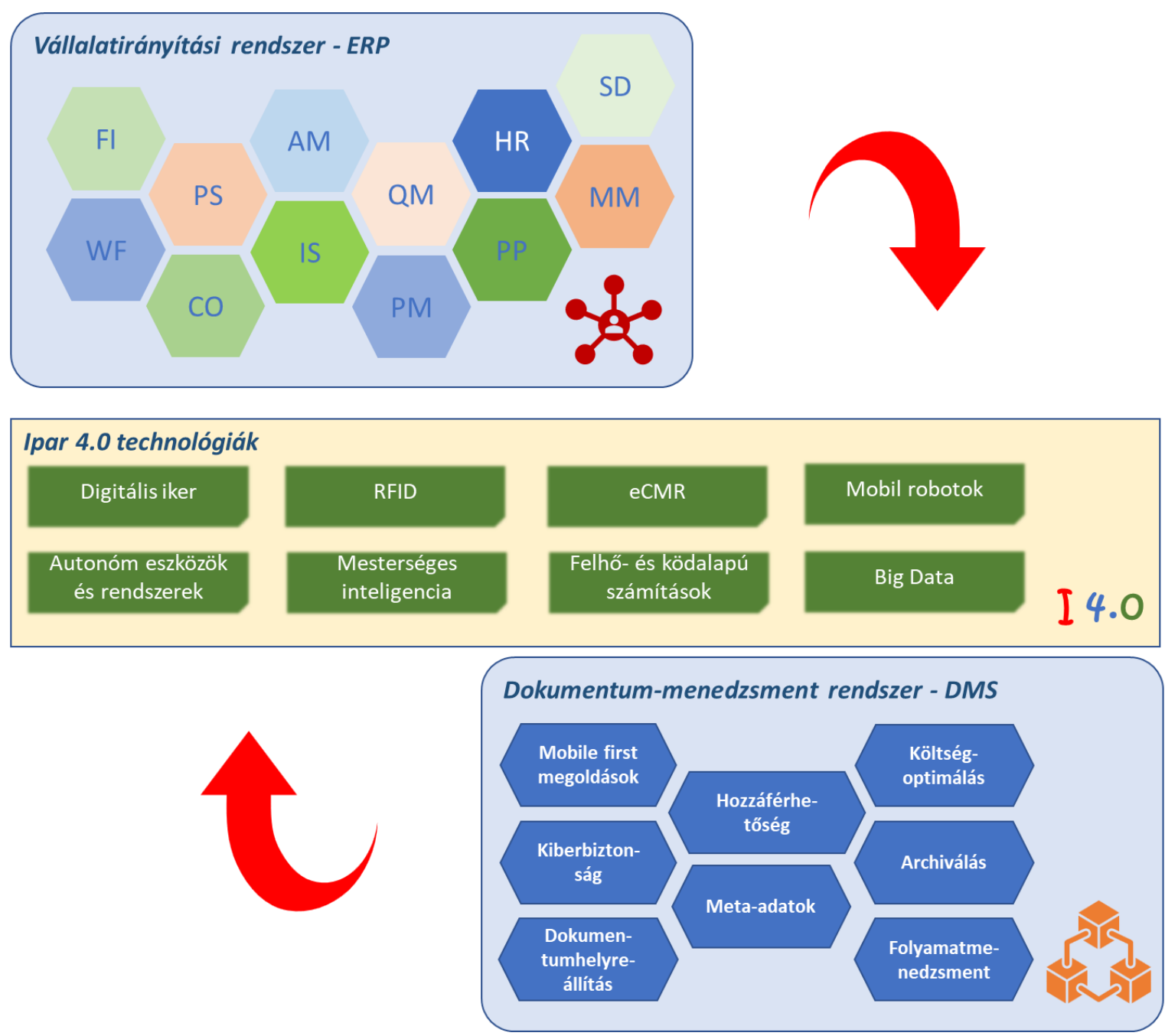

1. ábra. ERP és DMS integráció Ipar 4.0 technológiai háttérrel (v.ö. [8])

\section{Nagyvállalatok logisztikai dokumentációs környezetének digitalizációs aspektusai}

A dokumentáció kezelése jelentős költségekkel jár, amely nagyrészt az információ kezeléséhez szükséges eszközök és a humán erőforrás költségeiből tevődik össze. A kisebb cégek dokumentációs kollégái belefulladnak a papírmunkába és a legnagyobb fejtörést néhol az okozza, hogy hol lesz eltárolva 
a megannyi mappa a hatóságok által elöírt 5 éven keresztül. Azok a cégek ahol nincs szabad tőke az új generációs IT eszközökre a papír alapú információk (szállítólevelek, számlák, munkaórák) manuálisan kerülnek iktatásra és a céges tárhelyekre. Ez jelentős idő- és pénznyelő folyamat, melyből a kiút az Ipar 4.0.-nak köszönhető digitalizációs forradalom, amely a nagyvállalatokat már elérte. A digitalizáció tőkeigénye tagadhatatlan, azonban a megtérülés és a minőségi javulás sem marad el. Elég csak az ematricára gondolni, aminek köszönhetően indulás elött már nem kell megállni a benzinkúton. Valamint ha a soför elvéti a lehajtót már nem kell a cégeknek azonnal bírságot fizetni, mert az online rendszerrel egy órán belül visszamenőleg is meg lehet vásárolni az útdíjat. Az ilyen és ehhez hasonló rendszerek jelentősen megkönnyítették a fuvarozók életét bármilyen befektetés nélkül. Azonban mi van akkor, ha egy cég tökét fektet a digitalizációba?

A digitalizáció megkönnyíti a kommunikációt, az információk gyorsabb, pontosabb áramlását. Az intelligens megoldások és az egymással hálózatba kapcsolt rendszerek segítségével könnyebben megoldhatóvá és hatékonyabbá tehetőek a gépek, berendezések, valamint a logisztika szereplői és termékek egymással való kommunikációja. Ezzel a szállítmányozás és a raktározás területén is új lehetőségek nyílnak. Napi szinten a cégek, az intelligens hálózatok, a magánszektor és az egyéni felhasználók világszerte óriási mennyiségü adathalmazt állítanak elő. Ezek megfelelő elemzésével, szürésével javítható az elörejelzések hatékonysága, ezzel megkönnyítve a logisztikai tervezést is. Ez a nagy mennyiségü adatelőállítás többnyire annak köszönhető, hogy az ellátási lánc mentén az információk nagy részét elektronikusan továbbítják és dolgozzák fel. Ezek az adatok a logisztika teljes területéröl származhatnak különféle szenzorokból, vonalkódokból, fuvarozási adatokból, raktározási kapacitásadatokból és ezen különböző rendszerek sokrétü kommunikációjából.

A versenyképesség és a hatékonyság növelése szempontjából nélkülözhetetlen ezen adathalmazok szinte azonnali feldolgozása, elemzése és értékelése. Ezért elengedhetetlen az IoT megoldások alkalmazása és a különféle rendszerek egy univerzális hálózatba kapcsolása. A teljes logisztikai ágazat profitál az új technológiai korból, elég csak a régóta és már a mindennapok részévé vált GPSnavigációra, valós idejű időjárás-előrejelzésre vagy a Big Data elemzések alapján készülő fuvarszervezésre, illetve az "okos" konténerekre, raktárakra gondolni. Ezen kívül a digitalizáció következménye a digitális nyomkövetés elterjedése a rádiófrekvenciás RFID azonosítási segítségével [5].

A RFID azonosítás lényege, hogy egy chip memóriájában mentik el a szállítmány adatait, így azok olvasó kapu segítségével bármikor elérhetőek, meggyorsítva ezzel az azonosítás folyamatát. Továbbá a vonalkódos azonosítással ellentétben ez a technológia sokkal megbízhatóbb mivel nem olyan sérülékeny és bármikor aktualizálható és többször is felhasználható. Nem szükséges vizuális hozzáférés a chiphez mivel több méter távolságból is bemérhető a rádiókommunikációnak köszönhetően ezért bárhova elhelyezhetö. A kiadások és átvételek sorozata rögzíthető az RFID kapuk segítségével, így visszakereshetők például a hibajelzések és az összegyüjtött adatok segítségével ütemezhetjük a későbbi anyagáramlást. Megkönnyítik a szállítmányok nyomon követését és leltározását is a konténerekre és tehergépkocsikra szerelt RFID címkék.

$\mathrm{Az}$ eCMR vagy más néven elektronikus fuvarlevél is az adminisztrációs terhek csökkentése érdekében jött létre. A papír alapú dokumentáció csökkentésével jelentősen áttekinthetőbbé és egyszerübbé tehető a fuvarlevelek kezelése. Mivel a CMR-t elektronikusan hozzák létre már a legtöbb raktárban így azt elegendő csak továbbítani a speditőr számára és elektronikus aláírással hitelesíteni. 


\section{Digitalizáció a raktárakban}

A digitalizáció a raktárakat is elérte, ez egyéb logisztikai folyamatokra is kihat, mivel a raktár kiszolgálási idejének csökkenése az egész fuvarszervezésre hatással van [20,21]. A számos újítás közül a dinamikus rámpamenedzsmentet, az AGV-t és a hang vezérelt munkafolyamatokat szeretném részletezni.

A rámpáknál feltorlódó várakozó kamionok sorának a kezelése minden vállalatnál jelentős probléma, melyet ütemezéssel igyekeznek kezelni. Azonban az ütemezés jelentősen hatékonyabbá tehető, ha valós idejű adatokkal dolgozhatunk. A GPS adatok segítségével kiküszöbölhető a dugóprobléma [22]. Ha a fuvarozó GPS adatai elérhetőek a raktár számára akkor azok összevetve az tényleges érkezési idővel (ETA), személyre szabott előrejelzés készíthető, aminek köszönhetően a fuvarozók időt takarítanak meg.

A raktáron belüli anyagáramlás optimalizálása érdekében jöttek létre a vezető nélküli rendszerek. Az AGV-t a vállalat irányítási rendszerhez csatlakoztatva 24 órán keresztül használhatjuk rutin feladatok elvégzésére, mint például az áru raktárból való kiszállítására a rakodási helyre. A beruházás mértéke igen nagy egy ilyen rendszer kiépítése során azonban 2-3 müszakos üzemeltetés esetén megtérül és garantált folyamatbiztonságot és megbízhatóságot nyújt a raktár számára.

A logisztikai központokban az elsőszámú feladat a teljesítménymutatók, a kiszolgálási idő és a pontosság maximalizálása. Egy megfelelőnek tűnő rendelési pontosság is komoly veszteségeket tud generálni. Ha például $98 \%$ rendelési pontossággal dolgozunk napi 5000 rendelés teljesítése mellett naponta, az $100 \mathrm{db}$ hibát jelent. Tegyük fel, hogy $1 \mathrm{db}$ hibát $500 \mathrm{ft}$ mérhető költséggel jár kompenzálni, így a napi 2\%-os hiba éves szinten 12,5 millió forintjába kerül a cégnek. Az anyagi vonzaton felül pedig a panaszok és a vevői elégedetlenség ronthatja a cég megítélését.

Ezen indokok miatt a papír alapú módszert számos technológiával igyekeznek kiváltani, mint például RF-alapú leolvasás, fényre szedés és hangvezérlés. Ezek közül a leghatékonyabb a hangvezérlés mivel segítségével 99,8-99,98\% -os pontosságot érhetünk el. A hangvezérelt kiszedés további előnyei, hogy a betanulási idők és a fenntartási költségek is csökkennek. A hangvzérelt munkafolyamatok alapja a raktár - irányítási rendszer, amely a szükséges adatokat kinyeri az adatbázisból majd utasítást ad a dolgozónak. Beszédhangot generál és elmondja a dolgozónak a cikkek helyét és a rendelési mennyiséget. A dolgozó az áru tárolási helyén olvasható számsor bemondásával igazolja a feladat teljesítését. A hangvezérlésnek köszönhetően a munkavállalónak nem vonja el semmi a figyelmét a végzett feladatról és nem kell megszakítania a rakodást a dokumentálás miatt. Így jelentősen nő a hatékonyság és csökken a hibafaktor. A fent részletezett lehetőségek nagyban hozzájárulhatnak az adott vállalat gazdasági sikereihez. Azonban ha egy vállalat éppen új üzemet vagy esetleg üzemcsoportot épít, nem feltétlenül az automata targoncákat szerzik be elsőként.

\section{5. Összefoglalás}

Jelen cikkben bemutattuk a múlt, jelen és jövő megoldásait a dokumentálási folyamatokban rejlö kihívásokra. Vizionáltuk a mai megoldási módszerek és eljárások a nehézségeit, illetve gazdasági hatásait. Ismertettük a vállalatirányítási rendszerekben rejlő lehetőségeket és részleteztük azon digitalizációs rendszereket, melyeknek alapja egy ERP rendszer. Ezek komplex megoldást nyújtanak az egyes logisztikai területek optimalizálására a dokumentációs teher csökkentése mellett.

Munkánk során a logisztikai modulokkal harmonizálható rendszereket vizsgáltuk. Kutatásaink során különös figyelmet fordítottunk a raktár-gazdálkodási komponensre (WM- Warehouse Management). A WM modulhoz számos optimalizálási rendszer kapcsolható, ezek közül kiemelnénk a hangalapú 
vezérlést, az AGV-t és a dinamikus rámpamenedzsmentet. A szállítmányozást is megreformálták a digitalizációs lehetőségek, gondoljunk csak az RFID vagy az eCMR által nyújtott könnyedségekre.

\section{Köszönetnyilvánítás}

A cikkben ismertetett kutató munka az EFOP-3.6.1-16-2016-00011 jelü „Fiatalodó és Megújuló Egyetem - Innovatív Tudásváros - a Miskolci Egyetem intelligens szakosodást szolgáló intézményi fejlesztése" projekt részeként - a Széchenyi 2020 keretében - az Európai Unió támogatásával, az Európai Szociális Alap társfinanszírozásával valósul meg.

\section{Irodalom}

[1] PlanIO: Powerfully adaptable cloud storage. URL: https://try.plan.io/cloud-storage-gdmlp/?ref=capterra-document-management\&utm_source=capterra. Letöltve: 2020.07.12.

[2] REvvSales: Run your business one document at a time. URL: https://www.revvsales.com/. Letöltve: 2020.07.14.

[3] Bitrix24. URL: https://www.bitrix24.com/solutions/. Letöltve: 2020.07.22.

[4] Legito: Smart Document Workspace. URL: Smart Document Workspace: Letöltve: 2020.07.10.

[5] Notion: Organize your team's work. URL: https://www.notion.so/teams. URL: https://www.notion.so/teams: Letöltve: 2020.06.25.

[6] Xpertdoc: Document generation and automation products. URL: https://www.xpertdoc.com/en/products/. Letöltve: 2020.07.25.

[7] Siscin: Full Visibility of file data for minimisation and e-discovery. URL: https://waterfordtechnologies.com/siscin-capterra/. Letöltve: 2020.06.17.

[8] Panagides, A. The future of work: rethinking document management systems. URL: https://medium.com/datadriveninvestor/the-future-of-work-rethinking-document-managementsystems-dms-3ae31869aa2a. Letöltve: 2020.05.22.

[9] Using SharePoint as a Document Management System: URL: https://msftblog.com/usingsharepoint-as-a-document-management-system/. Letöltve: 2020.05.14.

[10] Bettermann, S., Kandelhard, F., Moritz, H.U., Pauer, W.: Digital and lean development method for 3D-printed reactors based on CAD modeling and CFD simulation, Chemical Engineering Research and Design 2019, 152:71-84. https://doi.org/10.1016/j.cherd.2019.09.024

[11] Vanichchinchai, A.: The effect of lean manufacturing on a supply chain relationship and performance, Sustainability 2019, 11(20):5751. https://doi.org/10.3390/su11205751

[12] Perez-Pucheta, C. E., Olivares-Benitez, E., Minor-Popocatl, H., Pacheco-Garcia, P. F., PerezPucheta, M. F.: Implementation of lean manufacturing to reduce the delivery time of a replacement part to dealers: A case study, Applied Sciences-Basel 2019, 9(18):3932. https://doi.org/10.3390/app9183932

[13] Villalba-Diez, J., Zheng, X. C., Schmidt, D., Molina, M.: Characterization of Industry 4.0 lean management problem-solving behavioral patterns using EEG sensors and deep learning, Sensors 2019, 19(13):2841. https://doi.org/10.3390/s19132841

[14] Jimenez, M., Romero, L., Fernandez, J., Espinosa, M. D., Dominguez, M.: Extension of the lean $5 S$ methodology to $6 S$ with an additional layer to ensure occupational safety and health levels, Sustainability 2019, 11(14):3827. https://doi.org/10.3390/su11143827

[15] De Vin, L. J., Jacobsson, L., Odhe, J.: Simulator-assisted lean production training, Production and Manufacturing Research - An Open Access Journal 2019, 7(1):433-447. https://doi.org/10.1080/21693277.2019.1644248 
[16] Uriarte, A. G., Ng, A. H. C., Moris, M. U.: Bringing together lean and simulation: a comprehensive review, International Journal of Production Research 2019, 58(1):87-117. https://doi.org/10.1080/00207543.2019.1643512

[17] Grosu, V., Anisie, L., Hrubliak, O., Ratsa, A.: Managerial accounting solutions: Lean Six Sigma application in the woodworking industry, A Practical aspect. Economic Annals-XXI 2019, 176(3-4):118-130. https://doi.org/10.21003/ea.V176-12

[18] Meng, X. H.: Lean management in the context of construction supply chains, International Journal of Production Research 2019, 57(11):3784-3798. https://doi.org/10.1080/00207543.2019.1566659

[19] Chen, P. K. Fortuny-Santos, J., Lujan, I., Ruiz-de-Arbulo-Lopez, P.: Sustainable manufacturing: Exploring antecedents and influence of Total Productive Maintenance and lean manufacturing, Advances in Mechanical Engineering 2019, 11:1687814019889736. https://doi.org/10.1177/1687814019889736

[20] Baker, P., Halim, Z.: An exploration of warehouse automation implementations: cost, service and flexibility issues, Supply Chain Management 2007, 12(2):129-138. https://doi.org/10.1108/13598540710737316

[21] Custodio, L., Machado, R.: Flexible automated warehouse: a literature review and an innovative framework, The International Journal of Advanced Manufacturing Technology 2020, 106:533558. https://doi.org/10.1007/s00170-019-04588-z

[22] Arora, Y.: GPS and its applications, International Journal of Latest Trends in Engineering and Technology 2017, 8(1):206-211. http://dx.doi.org/10.21172/1.81.027 